\title{
UJI HEPATOPROTEKTOR EKSTRAK ETANOL BUAH PEPINO (Solanum muricatum) TERHADAP TIKUS PUTIH JANTAN GALUR WISTAR YANG DIINDUKSI CCL4
}

\section{Hepatoprotector Test Of Fruit (Solanum Muricatum) Ethanol Extract Against Male White Rats Wistar Induced $\mathrm{By} \mathrm{Ccl}_{4}$}

\author{
Muhammad Asri.SR, Ummu Kalsum.T, Putri Suci Andriani \\ Universitas Megarezky
}

Email : muhammadasri324@gmail.com

\begin{abstract}
ABSTRAK
Buah pepino memiliki kandungan seyawa yaitu alkaloid, flavonoid, vitamin C yang dapat berkhasiat sebagai hepatoprotektor. Penelitian ini bertujuan untuk mengetahui aktivitas hepatoprotektor ekstrak etanol buah pepino (Solanum muricatum) terhadap tikus putih jantan yang diinduksikan ccl4 dengan dosis ekstrak dibagi menjadi tiga kelompok yaitu $100 \mathrm{mg} / \mathrm{kgBB}, 200 \mathrm{mg} / \mathrm{kgBB}$ dan $400 \mathrm{mg} / \mathrm{kgBB}$. Penelitian ini merupakan jenis eksperimental menggunakan rancangan penelitian True Experimental design. Pengujian aktivitas hepatoprotektor dengan parameter acuan nya adalah kadar SGOT dan SGPT. Analisis hasil pengukuran SGOT dan SGPT dihitung dengan menggunakan ANOVA satu arah. Hasil pengukuran kadar SGPT dan SGOT dengan dosis $100 \mathrm{mg} / \mathrm{kgBB}, 200 \mathrm{mg} / \mathrm{kgBB}$ dan 400 $\mathrm{mg} / \mathrm{kg}$ BB terjadi penurunan yang berbeda-beda .Pada SGOT penurunan tertinggi kadar terdapat pada ekstrak etanol buah pepino $100 \mathrm{mg} / \mathrm{kgBB}$ diikuti ekstrak etanol buah pepino $200 \mathrm{mg} / \mathrm{kgBB}$ lalu kelompok ekstrak etanol buah pepino $400 \mathrm{mg} / \mathrm{kgBB}$ kemudian kelompok positif dan terakhir kelompok negative .Dan pada SGPT penurunan kadar SGPT tertinggi pada kelompok control positif diikuti kelomok ekstrak etanol buah pepino dengan konsentrasi $100 \mathrm{mg} / \mathrm{kgBB}$, lalu ekstrak etanol buah pepino dengan konsentrasi $200 \mathrm{mg} / \mathrm{kgBB}$, kemudian konsentrasi $400 \mathrm{mg} / \mathrm{kgBB}$ dan terakhir kelompok control negative. Berdasarkan penelitian yang telah dilakukan, dapat disimpulkan bahwa buah pepino (Solanum muricatum) memiliki aktivitas hepatoprotektor pada konsentrasi $100 \mathrm{mg} / \mathrm{kgBB}$ pada kadar SGPT dan SGOT .
\end{abstract}

Kata kunci : Karbon tetraklorida, Hepatoprotektor, buah pepino.

\section{ABSTRACT}

Pepino fruit contains compounds such as alkaloids, flavonoids, vitamin $C$ which can be efficacious as a hepatoprotector. This study aims to study the activity of the ethanol hepatoprotector extract of pepino fruit (Solanum muricatum) against male white rats induced by ccl4 with extract extract into three groups namely $100 \mathrm{mg} / \mathrm{kg}, 200 \mathrm{mg} / \mathrm{kg}$ and $400 \mathrm{mg} / \mathrm{kg}$. This research is an experimental type using a true experimental design research design. Testing of hepatoprotector activity with reference parameters is SGOT and SGPT levels. Analysis of the results of the SGOT and SGPT measurements were calculated using one-way ANOVA. The results of the measurement of SGPT and SGOT levels with a dose of $100 \mathrm{mg} / \mathrm{kgBW}, 200 \mathrm{mg} / \mathrm{kgBW}$ and $400 \mathrm{mg} / \mathrm{kgBW}$ were different. $200 \mathrm{mg} / \mathrm{kgBB}$ then pepino fruit ethanol extract group $400 \mathrm{mg} / \mathrm{kgBB}$ then the positive group and finally the negative group. pepino with a concentration of 200 $\mathrm{mg} / \mathrm{kg}$, then a concentration of $400 \mathrm{mg} / \mathrm{kg}$ and finally the negative control group. Based on research that has been done, it can be concluded that the pepino fruit (Solanum muricatum) has hepatoprotector activity at a concentration of $100 \mathrm{mg} / \mathrm{kgBW}$ at SGPT and SGOT levels.

Keywords : Karbon tetraklorida, Hepatoprotektor, buah pepino.

\section{PENDAHULUAN}

Hati adalah kelenjar terbesar dalam tubuh, yang terletak dibagian teratas dalam rongga abdomen sebelah kanan dibawah diafragma. Hati juga disebut sebagai detoksikasi (mengamankan racun). (Pearce, 2009). Besarnya potensi kerusakan hati dapat dicegah dengan pemberian senyawa yang bertindak sebagai zat pelindung hati (hepatoprotektor). Senyawa alami yang dapat bertindak sebagai pelindung hati (hepatoprotektor) ialah antioksidan. Antioksidan merupakan senyawa yang dapat menghambat reaksi oksidasi dengan mengikat radikal bebas dan molekul yang sangat reaktif, akibatnya kerusakan sel akan dihambat (Winarsi, 2007). Buah pepino atau sering disebut buah melodi memiliki tampilan yang mirip dengan terung, memiliki kulit yang bercorak garigaris membujur. Hasil penelitian yang dilakukan oleh Husnah (2009) pada uji identifikasi golongan senyawa antioksidan pada ekstrak kasar buah pepino (Solanum muricatum) menunjukkan bahwa ekstrak etanol $70 \%$ buah pepino mempunyai golongan senyawa antioksidan berupa asam askorbat dan alkaloid yang dapat berpotensi dijadikan sumber antioksidan yang dapat menghambat kerja radikal bebas. Pengujian aktivitas hepatoprotektor 
dapat dilakukan baik secara in vivo maupun in vitro. Parameter acuanya adalah kadar Serum Glutamic Oxaloacetic Transminase (SGOT) yaitu Alanin Transminase (AST) dan Serum Glutamic Piruvic Transminase (SGPT) yaitu Aspartat Transminase). Keduanya merupakan enzim transaminase yang berfungsi mengkatalisis reaksi kimia yang terjadi dalam sel. Ketika terjadi serangan pada sel hati yang dapat disebabkan oleh senyawa obat yang toksik terhadap hati, mikroorganisme, dan sebagainya, maka akan terjadi perubahan permeabilitas pada membrane sel sehingga enzim - enzim yang seharusnya berada di dalam sel dapat keluar sel dan berada dalam darah. Oleh karena itu disebut transaminase serum, dengan kata lain enzim tersebut terdeteksi berada didalam serum (darah) dimana apabila tidak terjadi gangguan atau kerusakan pada sel hati maka enzim tersebut tidak terdeteksi dalam jumlah sedikit sekali di dalam darah. Berdasarkan uraian diatas, peneliti tertarik melakukan pengujian terhadap aktivitas hepatoprotektor ekstrak buah pepino (Solanum muricatum) pada tikus putih jantan (Rattus norvegicus) yang diinduksikan $\mathrm{CCl}_{4}$.

\section{METODE}

Jenis penelitian ini adalah penelitian eksperimental menggunakan rancangan penelitian True Experimental design. Dengan melakukan uji hepatoprotektor ekstrak buah pepino (Solanum muricatum) pada tikus putih jantan (Rattus norvegicus) yang diinduksikan $\mathrm{CCl}_{4}$. Analisis data secara statistic dengan uji One way Analysis of Variant (ANOVA), dilanjutkan dengan Post Hoc Test.

\section{BAHAN}

Air suling, buah pepino, Etanol 96 $\% \mathrm{CCl}_{4}$, reagen SGPT dan SGOT, Tikus (Rattus norvegicus), minyak kelapa dan $\mathrm{Na}$ - CMC 1\%, Eosin 1\%, Xilol, alcohol $70 \%$, Alkohol $96 \%$, alcohol $95 \%$, pereaksi mayer.

\section{Prosedur Kerja : \\ Penyiapan Sampel}

Buah pepino sebanyak $10 \mathrm{~kg}$ yang telah dicuci bersih dipotong-potong, kemudian dimasukkan ke dalam blender, diblender sampai halus tanpa penambahan air. Setelah itu diekstraksi menggunakan pelarut etanol $96 \%$ sampai seluruh sampel terendam. Ditutup rapat dan didiamkan selama 24 jam sambil beberapa kali dilakukan pengadukan, dan disaring. Ekstrak disaring sehingga mendapatkan filtrat I dan ampas. Filtrat I ditampung dan ampasnya kembali ditambah dengan etanol $96 \%$ sampai ampas terendam dibawah cairan penyari, dihomogenkan dan diekstraksi kembali dan dilakukan sebanyak tiga kali. Ekstrak cair yang diperoleh dipisahkan dari pelarutnya menggunakan rotary evaporator hingga diperoleh ekstrak kental.

\section{Perlakuan Hewan Coba}

Sebelum dilakukan uji pada tikus, dilakukan aklimatisasi terhadap lingkungan minimal satu minggu. Hewan uji dikelompokkan menjadi 5 kelompok yang masing-masing kelompok terdiri dari 3 ekor tikus. Satu hari sebelum perlakuan, semua tikus diambil darahnya untuk mengukur kadar SGPT \& SGOT dan sebelum perlakaun, Perlakuan selama tujuh hari :

Kelompok I adalah kelompok tikus yang diberikan curcuma FCT $3,6 \mathrm{mg} / 200 \mathrm{gram}$ sebagai kontrol postif, kemudian 1 jam setelah diberikan Curcum FCT diambil darah tikus untuk pengkuran kadar SGPT dan SGOT. Kelompok II adalah kelompok tikus yang diberikan $\mathrm{Na}-\mathrm{CMC} 1 \%$ sebagai kontrol negatif, kemudian 1 jam setelah diberikan akuades diambil darah tikus untuk pengkuran kadar SGPT dan SGOT. Kelompok III adalah kelompok tikus yang diberikan ekstrak etanol buah pepino dengan konsentrasi $100 \mathrm{mg} / \mathrm{BB}$ Tikus, kemudian 1 jam setelah diberikan ekstrak etanol buah pepino diambil darah tikus untuk pengkuran kadar SGPT SGOT. Kelompok IV adalah kelompok tikus yang diberikan ekstrak etanol buah pepino dengan konsentrasi $200 \mathrm{mg} / \mathrm{Kg}$ BB Tikus, kemudian 1 jam setelah diberikan ekstrak etanol buah pepino diambil darah tikus untuk pengkuran kadar SGPT dan SGOT. Kelompok $\mathrm{V}$ adalah kelompok tikus yang diberikan ekstrak etanol buah pepino dengan konsentrasi $400 \mathrm{mg} / \mathrm{BB}$ tikus, kemudian 1 jam setelah diberikan ekstrak etanol buah pepino diambil darah tikus untuk pengkuran kadar SGPT dan SGOT. Setelah hari ke delapan diinduksikan karbon tetraklorida dan pada hari ke sembilan diambil darah tikus untuk pengukuran akhir kadar SGPT dan SGOT. 


\section{Pengambilan Darah Dan Pengumpulan Serum \\ Pengambilan darah dilakukan} melalui ekor tikus dengan cara memotong ujung ekor tikus. Darah ditampung dalam tube vakum yang didalamnya terdapat antikoagulan (EDTA), lalu didiamkan selama 15 menit kemudian disentrifuge dengan kecepatan $3000 \mathrm{rpm}$ selama 15 menit, serum yang sudah terpisah dari endapan kemudian diambil dengan pipet $100 \mu \mathrm{l}$. Kemudian dilakukan pengukuran kadar SGPT dan SGOT.

\section{Pembuatan Preparat Histologi Hepar}

a. Tahap fiksasi

Hepar difiksasikan pada larutan formalin $10 \%$ selama $12-18$ jam .

b. Tahap dehidrasi

Hepar didehidrasi dengn menggunakan alkohol $70 \%, 96 \%$ dan 2 kali alkohol absolut masing-masing selama 1 jam.

c. Tahap clearing (penjernihan)

Hepar diclearing untuk menarik kadar alcohol dengan menggunakan xilol selama 1 jam.

d. Tahap embending Hepar diinfiltrasi dengan menggunakan paraffin dan dimasukkan ke dalam freezer selama 2 jam.

e. Tahap sectioning (pemotongan)
Hepar dipotong menggunakan mikrotom manual setebal 3 - 5 mikron dan potongan direkatkan pada kaca objek.

f. Tahap deparafinasasi

Perendaman dengan xilol 2 kali alcohol absolut, $70 \%, 95 \%$ dan $96 \%$ masingmasing selama 3 menit .

g. Tahap pewarnaan

1) Preparat direndam pada xilol 2 kali selama 2 menit

2) Direndam didalam alcohol absolut, $95 \%$ masing-masing selama 1 menit

3) Preparat direndam di dalam running tap water selama 5 menit

4) Preparat direndam dalam pewarnaan hematoksisilin selama 2 menit dan eosin $1 \%$ selama 2 menit, kemudian dimasukkan ke dalam alcohol $95 \%$ selama 2 menit, dan alcohol absolut selama 2 menit.

5) Preparat direndam pada xilol selama 2 menit

h. Tahap mounting

1) Slide dibiarkan kering pada suhu ruangan

2) Setelah slide kering siap untuk diamati dibawah mikroskop untuk Analisis Histopatologi.

\section{HASIL PENELITIAN}

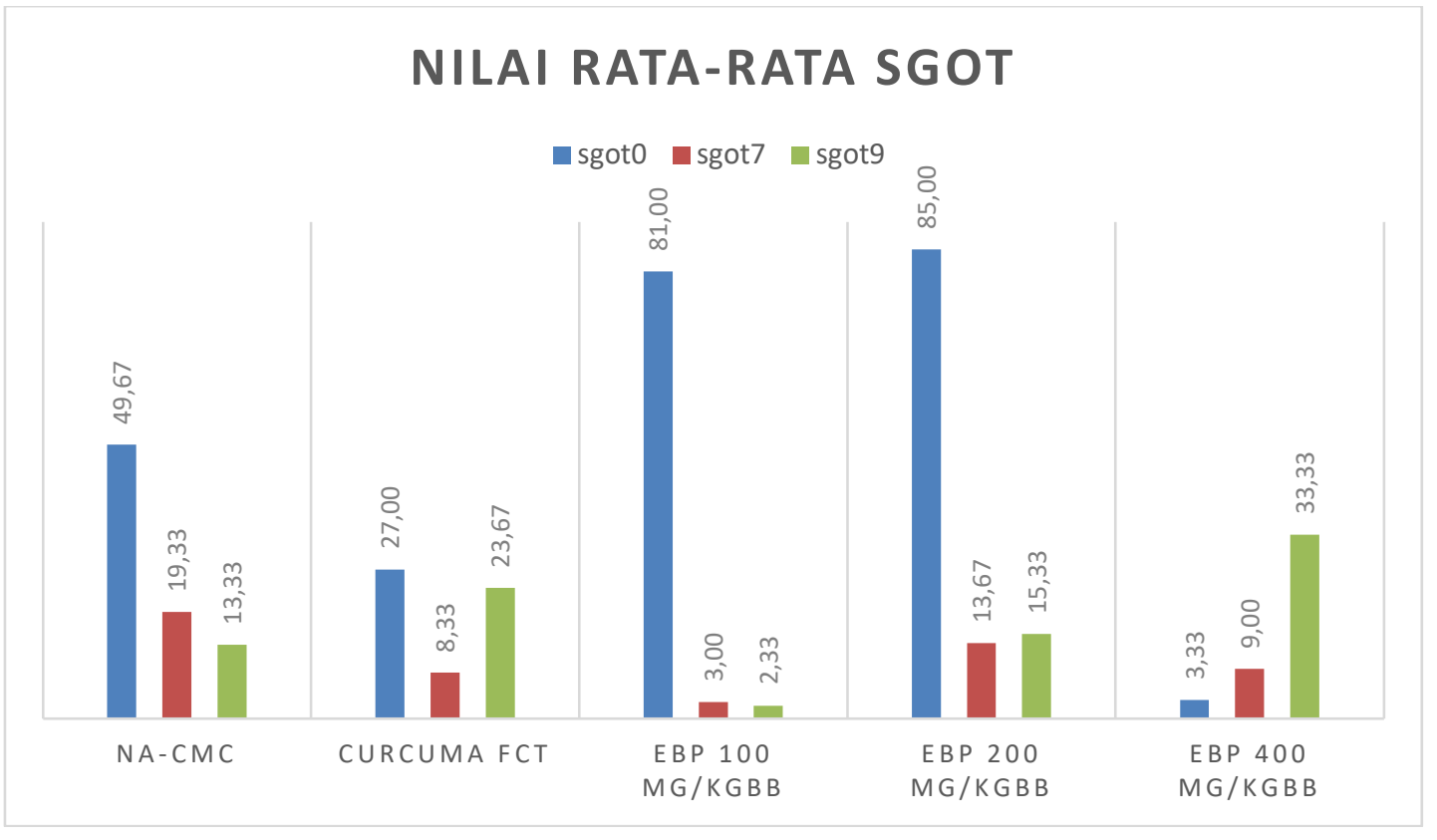

Grafik 1. Nilai rata-rata SGOT 


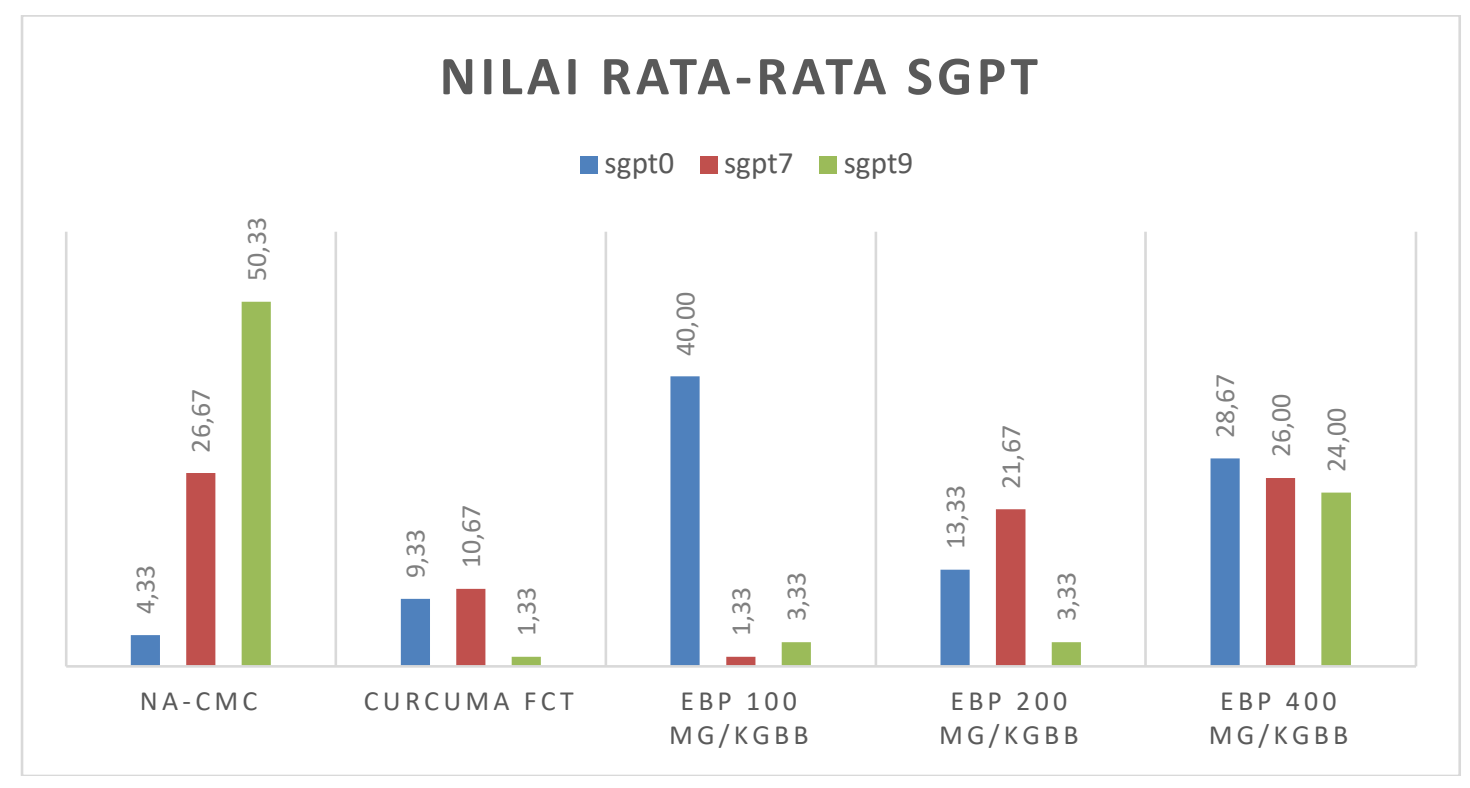

Grafik 2. Nilai rata-rata SGPT

\section{PEMBAHASAN}

Grafik 1. Peningkatan kadar SGOT dengan control negative yaitu $\mathrm{Na}-\mathrm{CMC}$ nilai rata-rata yang dimiliki yaitu 49,67 u/l, 19,33 u/l dan 13,33 u/l menunjukkan terjadinya penurunan kadar SGOT setelah pemberian ekstrak pepino maupun setelah penginduksian $\mathrm{CCl}_{4}$. Pada control positif nilai rata-rata yang didapatkan yaitu 27,00 $\mathrm{u} / \mathrm{l}, 8,33 \mathrm{u} / \mathrm{l}$ dan 23,67 u/l dimana terjadi penurunan setelah induksi ekstrak pepino dan terjadi peningkatan setelah induksi $\mathrm{CCl}_{4}$ namun peningkatan kadar SGOT yang terjadi masih dikatakan normal karena kadar normal SGOT pada tikus putih (Rattus norvegicus) yaitu 45,7 u/l - 80,8 u/l. Kadar SGOT pada kelompok ekstrak dengan konsentrasi $100 \mathrm{mg} / \mathrm{kg}$ BB yaitu $81,00 \mathrm{u} / \mathrm{l}, 3,00 \mathrm{u} / \mathrm{l}$ dan 2,33 u/l terlihat bahwa terjadi penurunan secara drastis setelah pemberian ekstrak pepino maupun setelah penginduksian $\mathrm{CCl}_{4}$ Pada kelompok ekstrak dengan konsentrasi 200 $\mathrm{mg} / \mathrm{kg}$ BB nilai rata-rata yang didapatkan yaitu $85,00 \mathrm{u} / \mathrm{l}, 13,67 \mathrm{u} / \mathrm{l}$ dan 15,33 u/l terlihat terjadi penurunan kadar SGOT yang sangat drastis, kenaikan yang dialami setelah penginduksian $\mathrm{CCl}_{4}$ masih dikatakan normal. Dan pada konsentrasi $400 \mathrm{mg} / \mathrm{kgBB}$ nilai rata-rata yang didapatkan yaitu 3,33 u/l, 9,00 u/l dan 33,3 $\mathrm{u} / \mathrm{l}$ terlihat terjadi peningkatan kadar SGOT setelah pemberian ekstrak maupun setelah penginduksian $\mathrm{CCl}_{4}$. Sedangkan Pada grafik 2. nilai rata-rata yang dimiliki oleh kelompok control negative yaitu 4,33 u/l, 26,67 u/l dan 50,39 u/l terjadi peningkatan kadar SGPT yang sangat tinggi setelah penginduksian $\mathrm{CCl}_{4}$. Kelompok control positif dengan nilai rata-rata 9,33 u/l, 10,67 $\mathrm{u} / \mathrm{l}$ dan 1,33 u/l terjadi penurunan kadar SGPT setelah induksi $\mathrm{CCl}_{4}$. Sedangkan pada kelompok eksrak dengan konsentrasi $100 \mathrm{mg} / \mathrm{kg}$ BB terlihat terjadi penurunan kadar SGPT setelah induksi ekstrak buah pepino (Solanum muricatum) pada ekstrak dengan konsentrasi $200 \mathrm{mg} / \mathrm{kg}$ BB nilai rata-rata yaitu 13, $33 \mathrm{u} / \mathrm{l}, 21,67 \mathrm{u} / \mathrm{l}$ dan 3,33 u/l. terlihat kadar SGPT setelah induksi $\mathrm{CCl}_{4}$ menurun. Sedangkan pada konsentrasi $400 \mathrm{mg} / \mathrm{kg}$ BB nilai rata-rata yang dimiliki 28,67 u/l, 26,00 u/l dan 24,00 $\mathrm{u} / \mathrm{l}$ terlihat bahwa kadar SGPT menurun setelah pemberian ekstrak dan penginduksian $\mathrm{CCl}_{4}$

Berdasarkan teori, ketika $\mathrm{CCl}_{4}$ berada didalam endoplasmic reticulum hati $\mathrm{CCl}_{4}$ akan dimetabolisme oleh sitrokrom P450 2 EI (CYP2EI) menjadi radikal bebas triklorometil $\left(\mathrm{CCl}_{3}\right)$. Pemberian $\mathrm{CCl}_{4}$ dalam dosis tinggi dapat merusak endoplasmic reticulum, mengakumulasi lipid, mengurangi sintesis protein, mengacaukan proses oksidasi dan dapat menyeabkan nekrosis sentribular serta degenerasi lemak dihati (Panjaitan, 2007). Pada nekrosis, perubahan paling jelas bermanifestasi pada inti sel yang menunjukkan satu dari 3 pola yaitu piknosis, kariolisis dan juga karioeksis. Parameter yang digunakan 
dalam dalam penilaian derajat kerusakan sel hepar dalam penelitian ini adalah jumlah inti sel yang mengalami piknosisi, kariolisis dan karioeksis. Gambaran histologi hepar tikus yang diberi ekstrak buah pepino (Solanum muricatum ) ditambah $\mathrm{CCl}_{4}$ pada konsentrasi $100 \mathrm{mg} / \mathrm{kg}$ BB menunjukkan tidak terjadi nya kerusakan pada sel hepar, dibandingkan dengan konsentrasi 200 $\mathrm{mg} / \mathrm{kg}$ BB menunjukkan kerusakan sel hepar yang lebih sedikit.. Pada histologi hepar dengan konsentrasi 400 mg/kg BB dan kelompok control negative mengalami kerusakan sel hepar yang sangat parah. Semakin besar konsentrasi ekstrak yang diberikan maka aktivitas antioksidannya akan meningkat. Jika antioksidan didalam tubuh melebihi batas maka aktivitas antioksidan akan berubah menjadi aktivitas prooksidan karena dapat mempengaruhi laju oksidasi. Gambaran inti piknosis, kariolisis dan karioeksis yang ditemukan pada kelompok kontol terjadi karena adanya proses apoptosis yang secara fisiologi dialami oleh semua sel normal (Yugo, 2011). Tanda jelas kematian sel terdapat dalam intinya. Biasanya sel yang telah mati intinya menyusut, tampak lebih padat, batasnya tidak teratur dan berwarna gelap (hiperkromatik), proses ini dinamakan piknosis dan intinya disebut piknotik. Kemungkinan lain, inti dapat hancur, robek dan meninggalkan pecahan-pecahan zat kromatin yang tersebar di dalam sel, proses ini disebut karioreksis. Pada beberapa keadaan, inti sel yang mati kehilangan kemampuan untuk diwarnai sehingga menjadi pucat dan menghilang begitu saja atau tidak nyata, proses ini disebut kariolisis (Rohmatin dkk, 2015).

\section{KESIMPULAN}

Berdasarkan penelitian yang telah dilakukan, dapat disimpulkan bahwa buah pepino (Solanum muricatum) memiliki aktivitas hepatoprotektor pada konsentrasi $100 \mathrm{mg} / \mathrm{kg}$ BB pada kadar SGPT dan SGOT.
DAFTAR PUSTAKA

Husnah, M. (2009). Golongan Senyawa Antioksidan Ekstrak Kasar Buah Pepino (Solanum muricatum Aiton) Berdasarkan Variasi Pelarut. Skripsi Jurusan Kimia Fakultas Sains dan Teknologi Universitas Islam Negeri (UIN) Malang Malang.

Pearce C. (2019) Anatomi Dan Fisiologi Untuk Paramedis. PT Gramedia Pustaka Utama. Jakarta.

Panjaitan, R. G. P., Handharyani, E., Chairul, M., Zakiah, Z., \& Manalu, W. (2007). Pengaruh pemberian karbon tetraklorida terhadap fungsi hati dan ginjal tikus. Makara Kesehatan, 11(1), 11-16.

Rohmatin, A. R., Susetyarini, E., \& Hadi, S. (2015). The Damage of Hepar Cells of White Male Mice (Rattus norvegicus) which are induced by Carbon Tetrachloride (CCl4) after being given Bawang Dayak (Eleutherine palmifolia Merr.) Ethanol Extract. In Proceeding Biology Education Conference: Biology, Science, Enviromental, and Learning (Vol. 12, No. 1, pp. 942-946).

Winarsi Hery. (2007). Antioksidan Alami Dan Radikal Bebas. PT KANISIUS. Yogyakarta.

Yugo. H.P., ( 2011). Uji Hepatoprotektor Jus Semangka Merah (Citrulus vulgaris) Terhadap Kerusakan Sel Hepar Tikus Putih (Rattus norvegicus) Akibat Paparan Parasetamol. Fakultas Kedokteran Universitas Sebelas Maret. 


\section{HISTOLOGI HATI}

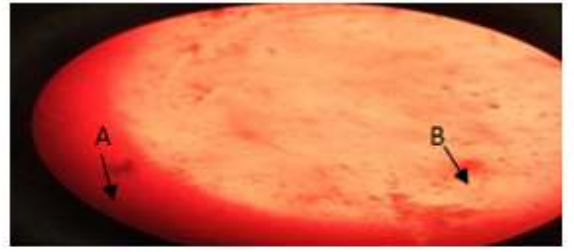

Kelompok I

A. Piknosis

B. Karioeksis

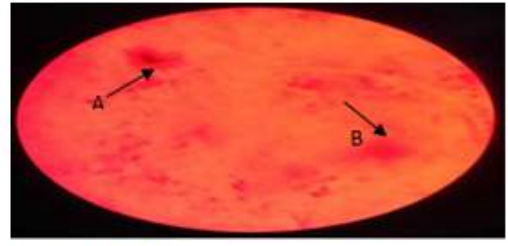

Kelompok II

A. Piknosis

B. Karioeksis

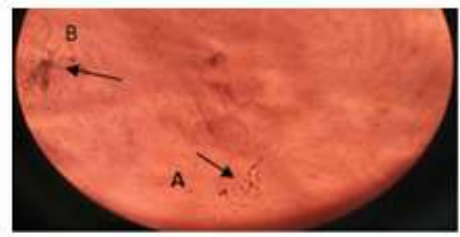

Kelompok IV

A. Sinusoid

B. Piknosis

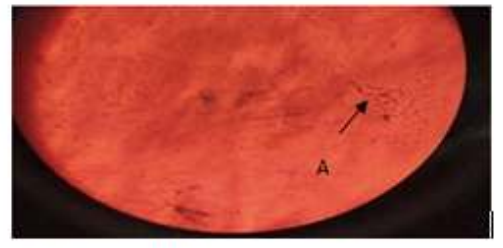

Kelompok III

A. Sinusoid

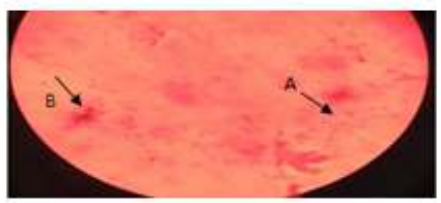

Kelompok V

A. Kariokesis

B. Piknosis 